\title{
Emergence of Groundnut ringspot virus and Tomato chlorotic spot virus in Vegetables in Florida and the Southeastern United States
}

\author{
Craig G. Webster, Galen Frantz, Stuart R. Reitz, Joseph E. Funderburk, H. Charles Mellinger, \\ Eugene McAvoy, William W. Turechek, Spencer H. Marshall, Yaowapa Tantiwanich, \\ Margaret T. McGrath, Margery L. Daughtrey, and Scott Adkins
}

First, seventh, eighth, and twelfth authors: U.S. Department of Agriculture, Agricultural Research Service, U.S. Horticultural Research Laboratory, Fort Pierce, FL 34945; second and fifth authors: Glades Crop Care, Inc., Jupiter, FL 33458; third author: Oregon State University, Department of Crop and Soil Science, Ontario, OR 97914; fourth author: University of Florida, Department of Entomology and Nematology, North Florida Research and Education Center, Quincy, FL 32351; sixth author: University of Florida/IFAS, Hendry County Extension, LaBelle, FL 33935; ninth author: Plant Pathology Research Group, Plant Protection Research and Development Office, Department of Agriculture, Ministry of Agriculture and Cooperatives, Chatuchuk, Bangkok, 10900, Thailand; and tenth and eleventh authors: Cornell University, Department of Plant Pathology and Plant-Microbe Biology, Long Island Horticultural Research and Extension Center, Riverhead, NY 11901.

Accepted for publication 7 October 2014.

\begin{abstract}
Webster, C. G., Frantz, G., Reitz, S. R., Funderburk, J. E., Mellinger, H. C., McAvoy, E., Turechek, W. W., Marshall, S. H., Tantiwanich, Y., McGrath, M. T., Daughtrey, M. L., and Adkins, S. 2015. Emergence of Groundnut ringspot virus and Tomato chlorotic spot virus in vegetables in Florida and the southeastern United States. Phytopathology 105:388-398.

Groundnut ringspot virus (GRSV) and Tomato chlorotic spot virus (TCSV) are two emerging tospoviruses in Florida. In a survey of the southeastern United States, GRSV and TCSV were frequently detected in solanaceous crops and weeds with tospovirus-like symptoms in south Florida, and occurred sympatrically with Tomato spotted wilt virus (TSWV) in tomato and pepper in south Florida. TSWV was the only tospovirus detected in other survey locations, with the exceptions of GRSV from to-

mato (Solanum lycopersicum) in South Carolina and New York, both of which are first reports. Impatiens (Impatiens walleriana) and lettuce (Lactuca sativa) were the only non-solanaceous GRSV and/or TCSV hosts identified in experimental host range studies. Little genetic diversity was observed in GRSV and TCSV sequences, likely due to the recent introductions of both viruses. All GRSV isolates characterized were reassortants with the TCSV M RNA. In laboratory transmission studies, Frankliniella schultzei was a more efficient vector of GRSV than $F$. occidentalis. TCSV was acquired more efficiently than GRSV by F. occidentalis but upon acquisition, transmission frequencies were similar. Further spread of GRSV and TCSV in the United States is possible and detection of mixed infections highlights the opportunity for additional reassortment of tospovirus genomic RNAs.
\end{abstract}

Tomato spotted wilt virus (TSWV), the type member of the genus Tospovirus in the family Bunyaviridae, is one of the most economically important plant viruses worldwide, infecting many vegetable and ornamental plant species $(24,28)$. TSWV has long been the major tospovirus problem of vegetable, peanut, and tobacco producers in the southeastern United States $(6,7,12)$. Two other tospoviruses, Impatiens necrotic spot virus and Iris yellow spot virus, occur in the southeastern United States (27). Recently, two additional tospoviruses previously not known to occur in the United States have emerged in vegetable production areas of south Florida.

Groundnut ringspot virus (GRSV) was first detected in tomato (Solanum lycopersicum) in late 2009 and subsequently in pepper (Capsicum annuum), tomatillo (Physalis philadelphica), and eggplant (Solanum melongena) in south Florida $(33,35)$. Tomato chlorotic spot virus (TCSV) was subsequently detected in tomato in south Florida in 2012 (20), and in tomato, pepper, jimsonweed (Datura stramonium), and lettuce (Lactuca sativa) in Puerto Rico $(13,32)$ and tomato in the Dominican Republic (3). TSWV remains present in all of these areas $(3,22,35)$. Diagnosis is

Corresponding author: S. Adkins, E-mail address: scott.adkins@ars.usda.gov

http://dx.doi.org/10.1094/PHYTO-06-14-0172-R

This article is in the public domain and not copyrightable. It may be freely reprinted with customary crediting of the source. The American Phytopathological Society, 2015 complicated due to visually indistinguishable symptoms: ringspots and necrotic and chlorotic areas are induced in tomato and pepper by GRSV, TCSV, and TSWV $(14,20,33,39)$. Additional hosts reported for GRSV and/or TCSV in other parts of the world include peanut (Arachis hypogaea; 9,11), coriander (Coriandrum sativum; 14,19), and lettuce (14), as well as several weeds $(4,14)$.

The genomes of GRSV and TCSV each consist of three RNA segments designated small (S), medium (M), and large (L), analogous to TSWV and other tospoviruses (reviewed in 36). The $\mathrm{S}$ RNA is ambisense and encodes a nucleocapsid (N) protein and a nonstructural silencing suppressor protein (NSs). The M RNA is also ambisense and encodes a precursor for two glycoproteins $\left(G_{N}\right.$ and $\mathrm{G}_{\mathrm{C}}$ ) and a nonstructural movement protein (NSm). The $\mathrm{L}$ RNA is negative sense and encodes a multifunction protein $(\mathrm{L})$ including an RNA-dependent RNA polymerase domain.

The tripartite genomes of tospoviruses, and members of the family Bunyaviridae in general, allow for reassortment (reviewed in 5). Such reassortment may occur between isolates of a single virus species as observed for TSWV $(25,31)$, or between virus species as observed for GRSV and TCSV in Florida (34). In fact, all isolates of GRSV characterized to date from Florida have an $\mathrm{L}_{\mathrm{G}} \mathrm{M}_{\mathrm{T}} \mathrm{S}_{\mathrm{G}}$ genotype with GRSV $\mathrm{S}$ and L RNAs and a TCSV $\mathrm{M}$ RNA. In contrast, the S, M, and L RNAs of TCSV isolates recently reported from Florida, Puerto Rico, and the Dominican Republic all share high levels of nucleotide identity with the corresponding RNAs of TCSV isolates from South America $(3,13$, 20,32), and thus have the standard TCSV genotype (i.e., are not 
interspecies reassortants). Similar to research with other members of the family Bunyaviridae (reviewed in 5), studies of reassortment between isolates of TSWV suggest novel biological properties can arise (e.g., TSWV N-gene-derived resistance breaking; 26) from this process. Biological properties of interspecies tospovirus reassortants, like Florida GRSV isolates, have not been characterized.

Virus species must occur sympatrically for reassortment to be possible (5). We define sympatry as the occurrence of different virus species infecting the same host species in a given geographic area at the same time. The presence of a common host species, plant or thrips, makes it possible for multiple virus species to infect a single individual of that species, which enables reassortment if co-infection of a plant host or insect vector occurs. For much of this study, GRSV, TSWV, and TCSV occurred sympatrically in south Florida. GRSV and TSWV were observed to occur in the same tomato fields and occasionally co-infect the same tomato plant in south Florida at the start of the study (33, 34). Beginning in 2012, TCSV was reported to occur in tomato in one of the same counties (Miami-Dade County) from which GRSV and TSWV were also reported in south Florida $(20,35)$.

Tospovirus transmission occurs exclusively by thrips (order Thysanoptera) but relatively few thrips species are known to acquire and transmit tospoviruses $(27,36)$. Feeding by recently hatched larvae on tospovirus-infected host plants is required for the successful acquisition (including infection of thrips cells by virus) and transmission (subsequent migration of virus to the salivary glands and delivery to noninfected plants), as previously reviewed (36). Viruliferous winged adult thrips are able to migrate and disseminate the virus. Transmission efficiencies vary by virus source, virus isolate, and thrips population $(10,15,16,37)$, and therefore local knowledge of virus isolates and thrips populations is necessary to identify which thrips species are most likely to transmit tospoviruses in a given geographic area.

The western flowers thrips (Frankliniella occidentalis) is a major vector of several tospoviruses, including TSWV, GRSV, and TCSV, and is widespread in the United States and much of the world $(27,34,37)$. The common blossom thrips (F. schultzei) is also an efficient vector of TSWV, GRSV, and TCSV in South America but this species is not widespread in the United States $(23,27,37)$. However, $F$. schultzei has recently been reported in vegetable production areas where GRSV and/or TCSV have been detected in the continental United States and Puerto Rico (13, 17,18,32). The potential of other thrips species to transmit GRSV or TCSV isolates in Florida has not been determined. This includes the Florida flower thrips ( $F$. bispinosa) and tobacco thrips (F. fusca) that are known to transmit tospoviruses (27) and are commonly found in the southeastern United States.

Vegetable production in the southeastern United States shifts north from Florida to other states during spring and summer and returns south to Florida during the fall and winter to follow suitable growing conditions. A wide variety of vegetable and other crops, many of which may be GRSV and/or TCSV hosts, are grown throughout the eastern United States. Therefore, we determined experimental host ranges of Florida GRSV and TCSV isolates with particular emphasis on important crop and weed species. Although TSWV is well known in most major U.S. vegetable production areas, the extent of spread of GRSV and TCSV beyond south Florida is not known. We used surveys of GRSV, TCSV, and TSWV across major tomato growing regions of Florida and the southeastern United States to investigate the establishment of GRSV and TCSV and determine the current geographic range and potential for further spread and/or reassortment of these viruses. We also examined the genetic diversity of all GRSV and TCSV isolates collected from new hosts and new locations during this study. Finally, we evaluated the ability of several important thrips species to transmit GRSV and TCSV. Collectively, the results of this research provide a current assess- ment of these emerging tospoviruses in the southeastern United States and the foundation for improved management strategies.

\section{MATERIALS AND METHODS}

Isolation and maintenance of tospoviruses. Two single local lesion-passaged GRSV isolates and one single local lesionpassaged TSWV isolate from tomatoes in Florida were maintained as described previously (34). A TCSV isolate collected from tomato in southwest Florida was similarly maintained. Local lesions of TCSV and selected newly collected GRSV isolates were generated by mechanical inoculation of Nicotiana glutinosa using $0.5 \%$ (wt/vol) sodium sulfite. A single local lesion was excised and used to mechanically inoculate systemic tospovirus hosts including American black nightshade (Solanum americanum), jimsonweed (Datura stramonium), tomato, and pepper. These local lesion-passaged GRSV and TCSV isolates were used for host range and transmission experiments.

Plants sources and inoculations. For the majority of plants in host range experiments, commercially available seeds were used (Johnny's Selected Seeds, Winslow, ME; Burpee Seeds and Plants, Warminster, PA; Asgrow, St. Louis, MO). Weed and indicator host species were grown from seeds produced from virusfree source plants in the USHRL greenhouse. Brugmansia (Brugmansia $\times$ candida), Key West nightshade ( $S$. bahamense), and strawberry (Fragaria $\times$ ananassa) were propagated from virusfree stock plants. Plants were kept in an air conditioned greenhouse under natural lighting with a daytime maximum temperature of $30^{\circ} \mathrm{C}$.

For host range experiments, 10 plants of each species or cultivar were mechanically inoculated as described above at the two to three true leaf stage. Two plants of each species or cultivar were mock inoculated with sodium sulfite solution. Inoculated and upper, noninoculated leaves were examined weekly for symptoms. The presence of virus in inoculated (locally infected) or upper, noninoculated (systemically infected) leaves was determined at 2 to 3 weeks postinoculation by using virus-specific tests as described below. For a few species or cultivars (e.g., impatiens and peanut with GRSV), several sets of plants were inoculated. To examine potential differences between mechanical and thrips inoculation, one set of eggplants was mechanically inoculated and a second set was exposed to an $F$. occidentalis population reproducing on TCSV-infected plants.

Geographic distribution of GRSV, TCSV, and TSWV. As a first step to analyze the geographic distribution of GRSV (and later TCSV), plants with typical tospovirus symptoms were collected by trained observers in the major vegetable production areas of Florida, Georgia, South Carolina, North Carolina, and the Eastern Shore of Virginia. These were primarily tomatoes but also included peppers, peanuts, and a variety of weeds. Symptomatic tomato transplants were also collected from transplant production facilities in Florida and symptomatic vegetable plant samples were collected in Indiana and Long Island, New York.

At the start of this study, collected samples were tested only for GRSV and TSWV because TCSV was not known to occur in the United States at that time, and no evidence of TCSV was found in 2009 and 2010 when GRSV was first detected in Florida (33-35). With the detection of TCSV in Florida in 2012 (20), all subsequent survey samples were tested for GRSV, TCSV, and TSWV using virus-specific assays as described below.

Detection of tospoviruses. Enzyme-linked immunosorbent assay (ELISA) and/or reverse transcription-polymerase chain reaction (RT-PCR) were used for tospovirus detection in all plant samples evaluated in this study as previously described $(33,34)$. Commercially available ELISA reagents for GRSV/TCSV or TSWV N protein detection were used according to the manufacturer's instructions (Agdia, Elkhart, IN). RNA was extracted (RNeasy Plant Mini Kit, Qiagen, Germantown, MD) and first 
strand cDNA synthesized using random hexamers and Moloney murine leukemia virus reverse transcriptase (Promega Corp., Madison, WI). Primers specific for the N gene of GRSV (33), TCSV (32), or TSWV (1) that produce PCR amplicons of 594, 519 , or $620 \mathrm{bp}$, respectively, were initially used.

Further sequence characterization of GRSV and TCSV isolates made use of additional primers to amplify a portion of the NSm (29) and the $\mathrm{L}$ genes $(32,33) . \mathrm{G}_{\mathrm{N}} \mathrm{G}_{\mathrm{C}}$ primers Glyco4vc $\left(5^{\prime}\right.$-AGC ATTCTGTTGTTCAGGGCTAC-3') and Glyco5v (5'-CAGAG TGTGCTTTGAAGTTCCC-3') were designed from the original Florida GRSV isolate sequence (34) and used for the GRSV isolates from South Carolina and New York. Isolates chosen for further sequencing represented all new hosts and new locations from which either GRSV or TCSV was detected for the first time during the geographic survey. Amplicons were excised from agarose gels, purified (QiaQuick gel purification kit, Qiagen), and ligated to pGEM-T (Promega). Six clones of each amplicon were sequenced in both directions on an ABI 3730XL automated sequencer at the USHRL DNA Sequencing Support Laboratory. Primer and plasmid sequences were removed and a single consensus sequence was obtained from the six clones of each amplicon using Vector NTI Advance software, Version 11 (Invitrogen, Carlsbad, CA). Consensus sequences were deposited in GenBank (accessions KM006992 to KM007037) and aligned using MEGA (Version 4.1 ; 30) with Clustal W and default parameters. Pairwise comparisons of nucleotides were made using the pairwise deletion option and the number of common sites and compared with sequences obtained from GenBank.

Thrips transmission of GRSV and TCSV. Thrips species known to transmit tospoviruses were collected from vegetables, weeds, and ornamentals in the Florida landscape and identified to the species level with a dissecting microscope. A colony of $F$. occidentalis was maintained on green bean (Phaseolus vulgaris) pods that were washed in $0.5 \%$ ( $\mathrm{vol} / \mathrm{vol}$ ) sodium hypochlorite and Veggie Wash (active ingredient: $1 \%$ citric acid, Beaumont Products, Inc., Kennesaw, GA). Typically, F. schultzei was collected from watermelon (Citrullus lanatus) or cucumber (Cucumis sativus) flowers, $F$. bispinosa was collected from crape myrtle (Lagerstroemia indica) flowers, and F. fusca was collected from perennial peanut (Arachis glabrata) flowers. However, $F$. bispinosa was found in flowers of all species.

Adults of each species were maintained in separate containers and allowed to oviposit onto bean pods for 2 to 3 days before being removed. First instar larvae were collected from bean pods within $24 \mathrm{~h}$ of emergence and placed on symptomatic leaves of GRSV- or TCSV-infected tomato 'Florida 47' or pepper 'Aristotle' source plants for acquisition and transmission experiments as previously described $(34,38)$. Source plants were of consistent plant age and mechanically inoculated with one of two local lesion-passaged GRSV isolates or one local lesion-passaged TCSV isolate. Prior to use in transmission experiments at 1 to 2 weeks postinoculation, infection of source plants with the expected virus was confirmed by RT-PCR testing for the $\mathrm{N}$ gene as described above. Initially, a single adult thrips that was fed as a larva on infected plants and had potentially acquired virus was moved to a single leaf disc (tomato 'Florida 47' or pepper 'Aristotle') placed on agar in $2.5 \mathrm{~cm}$ petri dishes and supplemented with Miracle Grow (The Scotts Company, Marysville, $\mathrm{OH}$ ). Although dishes were sealed with Parafilm (Pechiney Plastic Packaging Company, Chicago, IL), large numbers of thrips, especially $F$. bispinosa and $F$. fusca, escaped. In later experiments, a single thrips was instead placed on a single leaf disc in a $1.5-\mathrm{ml}$ microcentrifuge tube to prevent adult escape. Adult thrips were removed after 2 days on leaf discs. Identifications of thrips were confirmed and thrips were frozen $\left(-20^{\circ} \mathrm{C}\right)$ for later testing. Leaf discs were maintained for another 3 to 5 days after thrips removal during which time sterile water was added as needed to prevent dehydration of the discs. Ultimately, leaf discs were removed and frozen $\left(-20^{\circ} \mathrm{C}\right)$ for later testing. Thrips and leaf discs were tested for GRSV or TCSV by either RT-PCR $(\approx 10 \%$ of samples) or ELISA (remaining $\approx 90 \%$ of samples) as described previously (34) because single thrips and single leaf discs were found to contain too little virus to permit testing by both methods. An individual thrips and its corresponding leaf disc were always tested by the same method.

Acquisition and transmission of GRSV by four thrips species were compared through contingency table analyses. Where a significant difference among the species was detected, post-hoc multiple comparison tests were conducted to determine which pairs of species differed from one another (40). We further examined the frequency of successful transmission of GRSV by viruliferous thrips of different species using Fisher's exact test because of the small sample sizes for viruliferous thrips. Comparisons of GRSV and TCSV acquisition and transmission by $F$. occidentalis were also made using contingency table analyses, including the use of Fisher's exact test for comparison of transmission of GRSV and TCSV by viruliferous F. occidentalis. All analyses were conducted using SAS v. 9.2 (SAS Inc., Cary, NC).

\section{RESULTS}

Experimental host ranges of the emerging tospoviruses. Experimental host range tests of 45 species for GRSV and 18 species for TCSV included a range of important vegetable, ornamental, and weed species (Table 1). A more extensive host range was examined for GRSV due to it being a reassortant. All mock-inoculated plants remained virus-free.

GRSV and TCSV severely affected solanaceous species including vegetable, ornamental, and weed species. Symptoms induced by the two viruses were similar in commercial tomato and pepper cultivars and included necrosis, often of the growing point, ringspots, chlorotic or necrotic lesions, and mottle. In general, TCSVinfected plants expressed more severe symptoms than those infected with GRSV. Local and systemic movement of viruses was confirmed by ELISA and/or RT-PCR and typically correlated with the presence of symptoms, although in some cases (e.g., tomato 'Florida 47' infected with GRSV, and 'Tygress' infected with GRSV or TCSV) the virus was detected in inoculated leaves despite a lack of symptoms in these leaves. In most susceptible species, greater than $50 \%$ of the inoculated plants developed symptoms, indicating a high susceptibility to infection by mechanical inoculation. However, results of inoculations were inconsistent in brugmansia, eggplant, and tomato. For instance, local infections developed in seven brugmansia inoculated with GRSV and five eggplants inoculated with GRSV or TCSV, whereas systemic symptoms (with virus presence confirmed by RT-PCR) only developed in a single brugmansia and a single eggplant inoculated with GRSV. Although thrips inoculation of eggplant with TCSV essentially doubled the number of locally infected plants observed with mechanical inoculation from 50 to $92 \%$, no systemic infections were detected from either inoculation method. Tomato cultivars 'Black Cherry', 'Black Prince', 'Matt's Wild Cherry', 'Moskvich', 'Purple Calabash', and 'Quincy' developed no local or systemic symptoms following inoculation with GRSV, although four of these tomato cultivars ('Black Prince', 'Matt's Wild Cherry', 'Moskvich', and 'Purple Calabash') displayed systemic symptoms when inoculated with TCSV. In some species, symptoms progressed to plant death within 3 weeks of inoculation. This occurred most often with TCSV although it varied by species and, in some cases, by cultivar. For instance, 12 of 28 tomatillo 'Burpee Green' plants became systemically infected with GRSV, whereas 6 of 10 died following inoculation with TCSV and the remaining four plants were systemically infected. Only 1 of 10 petunia 'Blue Supercascade' plants was systemically infected with GRSV, whereas 8 of 10 were systemically infected with TCSV. In contrast, 6 of 10 petunia 'Red Super- 
cascade' plants died following GRSV inoculation with two of four remaining plants systemically infected, whereas only 1 of 10 died following TCSV inoculation with 8 of 9 remaining plants systemically infected. Flower break was observed in all petunia cultivars inoculated with GRSV but not with TCSV.

Although the majority of host plants identified for both viruses were solanaceous, impatiens inoculated with GRSV or TCSV and lettuce inoculated with TCSV were also infected (Fig. 1). Impatiens were locally and systemically infected with GRSV and TCSV but only plants infected with TCSV developed concentric necrotic rings (Fig. 1A) on upper, noninoculated leaves. Neither lettuce cultivar tested was infected with GRSV. TCSV only infected lettuce 'Parris Island', inducing small chlorotic spots on inoculated and upper, noninoculated leaves that turned necrotic and developed into larger necrotic areas spreading along the midrib of the leaf (Fig. 1B). In some cases, this led to collapse of inoculated leaves. Other important crop species, including water- melon, soybean and peanut, and common virus indicator hosts, including globe amaranth and lambsquarters, were not infected with either virus.

Geographic distribution of GRSV, TCSV, and TSWV. In 2013, we detected GRSV outside of Florida for the first time in tomato samples from South Carolina and New York (Fig. 2A). The South Carolina GRSV isolate was detected in a mixed infection with TSWV, and was identified following separation by local lesion-passage in $N$. glutinosa and RT-PCR amplification of portions of all three genomic RNA segments for each virus. The New York GRSV isolate was detected in a single infection although TSWV was common in other samples from this and nearby fields.

GRSV and TCSV were commonly identified in seven, and GRSV was detected in two more, of the ten counties surveyed in south Florida (Florida peninsula south of Orlando; Fig. 2B) although the percentage of south Florida tomato samples infected
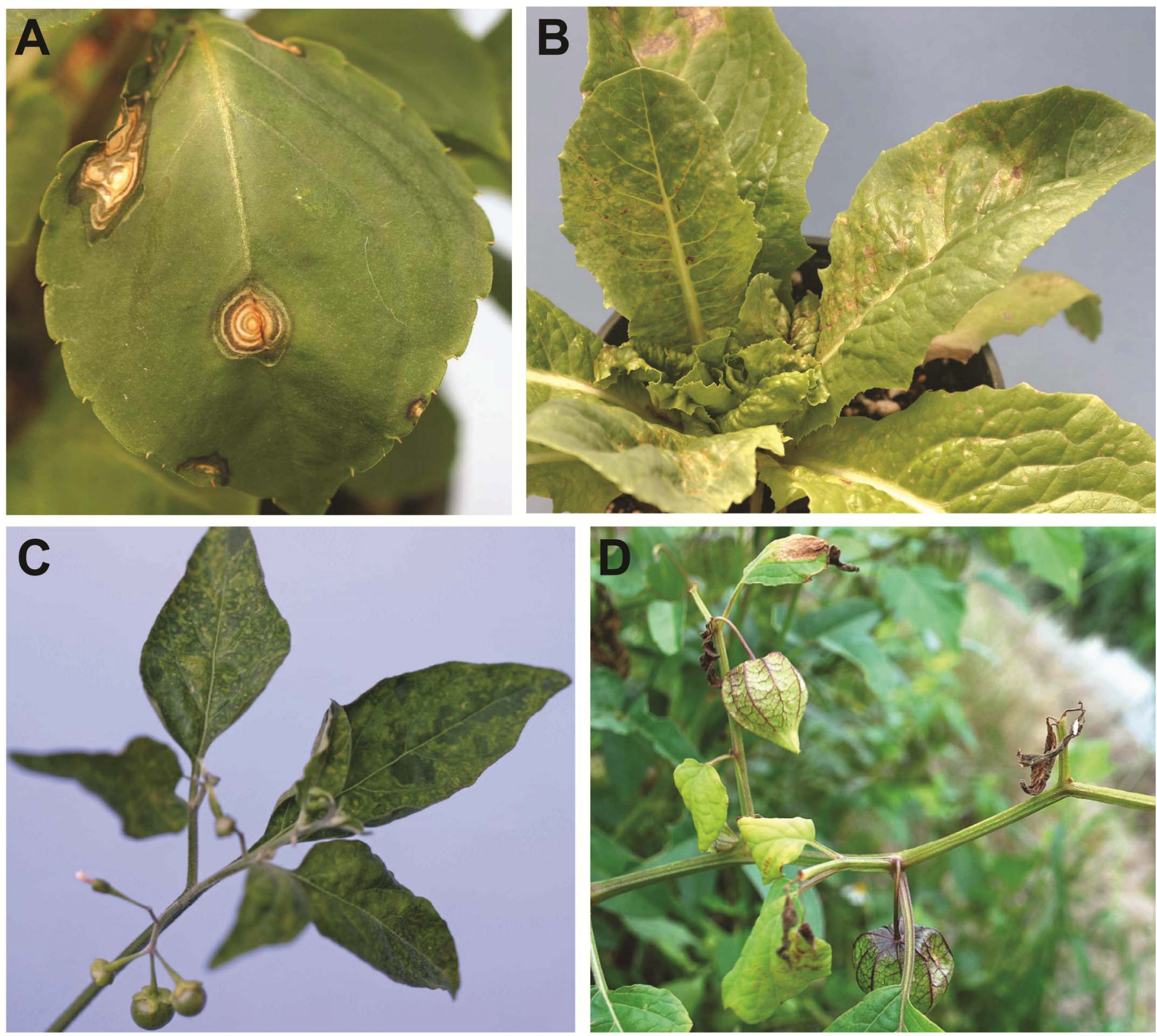

Fig. 1. Symptoms of Tomato chlorotic spot virus (TCSV) and Groundnut ringspot virus (GRSV) infection of mechanically and naturally infected hosts. A, Impatiens (Impatiens walleriana) mechanically inoculated with TCSV with concentric necrotic rings on noninoculated (systemically infected) leaf. B, Lettuce (Lactuca sativa) mechanically inoculated with TCSV with chlorotic and necrotic lesions on noninoculated (systemically infected) leaves. C, American black nightshade (Solanum americanum) found naturally infected with GRSV with chlorotic ringspots and ring patterns collected in 2011 in Collier County. D, Cutleaf groundcherry (Physalis angulata) found naturally infected with GRSV with necrotic growing points collected in 2011 in St. Lucie County. 
with GRSV decreased from 64\% in 2011 to $9 \%$ in 2013 (Table 2). TSWV was widespread on a range of solanaceous hosts throughout Florida and in the southeastern United States from 2011 through 2013 (Fig. 2A and B) and also in New York and Indiana. Although two or more viruses were often found in the same field, mixed infections of two tospovirus species in a single plant were not common. Only seven mixed infections were detected among the 431 infected samples detected in this study (Table 2). GRSV was not prevalent outside of south Florida, and TCSV was not found beyond south Florida. However, all three viruses occurred sympatrically in tomato and pepper in seven counties in south Florida (Collier, Hendry, Lee, Manatee, Miami-Dade, Palm Beach, and St. Lucie) during much of our study, and GRSV and TSWV occurred sympatrically in tomato in South Carolina and New York at least sporadically in 2013, fulfilling a major requirement for genome reassortment.

In south Florida, GRSV and TCSV were identified in tomato and/or pepper in several new counties: GRSV was detected in Charlotte, Lee, and St. Lucie Counties; TCSV was detected in Collier, Hendry, Manatee, Palm Beach, and St. Lucie Counties. Only TSWV was detected in north Florida (Fig. 2B). At the start of this research in 2011, only GRSV and TSWV were known to occur in the United States and it was not until after the detection and report of TCSV in 2012 (20) that TCSV was included in testing protocols. GRSV and TCSV were also identified several times each in tomato transplants from transplant production facilities in Florida. Broad spectrum tests for tospovirus were also conducted on selected samples to examine for additional tospoviruses and in all cases were negative (data not shown).

During the geographic survey, several new natural weed hosts for GRSV were identified including American black nightshade (Fig. 1C) and cutleaf groundcherry (Fig. 1D). Symptomatic weeds were collected adjacent to tomato or pepper plants infected with GRSV. Symptoms included ringspots and chlorosis on nightshade, and leaf distortion and necrosis of growing points on groundcherry, and were similar to those induced on mechanically inoculated plants in the greenhouse (Table 1). Neither GRSV nor TCSV was detected in any samples of other crop or weed species. TSWV was detected in peanut in both south and north Florida (Table 2).

The geographic distribution studies in this work considered only plants with typical tospovirus symptoms. Thus, our results do not necessarily reflect the true incidence of GRSV, TCSV, and TSWV in the hosts analyzed but rather document expansion of the known geographic distribution of GRSV and TCSV. Symptomatic samples were infrequent in all 3 years and typically made up less than $1 \%$ of the total planting, although higher incidences

TABLE 1. Plants used to establish experimental host range and symptoms of Groundnut ringspot virus (GRSV) and Tomato chlorotic spot virus (TCSV)

\begin{tabular}{|c|c|c|c|c|c|}
\hline Family, species, and cultivar ${ }^{\mathrm{u}}$ & Common name & $\begin{array}{c}\text { GRSV } \\
\text { symptoms }^{\mathrm{v}}\end{array}$ & $\begin{array}{c}\text { GRSV } \\
\text { presence }^{w}\end{array}$ & $\begin{array}{c}\text { TCSV } \\
\text { symptoms }^{\mathrm{v}}\end{array}$ & $\begin{array}{c}\text { TCSV } \\
\text { presence }^{w}\end{array}$ \\
\hline \multicolumn{6}{|l|}{ Amaranthaceae } \\
\hline Gomphrena globosa 'Strawberry Fields' & Globe amaranth & $-1-$ & 0 of $10 / 0$ of 10 & $\mathrm{nt}$ & $\mathrm{nt}$ \\
\hline \multicolumn{6}{|l|}{ Apiaceae } \\
\hline Coriandrum sativum & Coriander & $-1-$ & 0 of $10 / 0$ of 10 & $\mathrm{nt}$ & $\mathrm{nt}$ \\
\hline \multicolumn{6}{|l|}{ Asteraceae } \\
\hline Helianthus annuus 'Sunrich Orange Summer' & Sunflower & $-1-$ & 0 of $10 / 0$ of 10 & $\mathrm{nt}$ & nt \\
\hline Lactuca sativa 'Parris Island' & Lettuce & $-1-$ & 0 of $10 / 0$ of 10 & CL,N/CL,NL & 8 of $10 / 10$ of 10 \\
\hline L. sativa 'Cherokee' & Lettuce & $-1-$ & 0 of $10 / 0$ of 10 & $-1-$ & 0 of $10 / 0$ of 10 \\
\hline Zinnia elegans 'Giant Dahlia' & Elegant zinnia & $-1-$ & 0 of $10 / 0$ of 10 & nt & $\mathrm{nt}$ \\
\hline Rudbeckia hirta 'Prairie Sun' & Black-eyed Susan & $-1-$ & 0 of $10 / 0$ of 10 & nt & $\mathrm{nt}$ \\
\hline \multicolumn{6}{|l|}{ Balsaminaceae } \\
\hline Impatiens walleriana 'Athena Mix' & Impatiens & NL,RS/- & 4 of $20 / 1$ of 20 & N,RS/N,RS & 6 of $10 / 5$ of 10 \\
\hline \multicolumn{6}{|l|}{ Brassicaceae } \\
\hline Brassica oleracea 'Champion' & Collards & $-1-$ & 0 of $10 / 0$ of 10 & $\mathrm{nt}$ & nt \\
\hline B. oleracea 'Farao' & Cabbage & $-1-$ & 0 of $10 / 0$ of 10 & nt & nt \\
\hline B. oleracea 'Winterbor' & Kale & $-1-$ & 0 of $10 / 0$ of 10 & $-1-$ & 0 of $10 / 0$ of 10 \\
\hline \multicolumn{6}{|l|}{ Caryophyllaceae } \\
\hline Dianthus barbatus 'Hollandia Mix' & Sweet William & $-1-$ & 0 of $10 / 0$ of 10 & nt & $\mathrm{nt}$ \\
\hline \multicolumn{6}{|l|}{ Chenopodiaceae } \\
\hline Chenopodium amaranticolor & Lambsquarters & $-1-$ & 0 of $10 / 0$ of 10 & nt & nt \\
\hline C. quinoa & Lambsquarters & $-1-$ & 0 of $20 / 0$ of 20 & $-1-$ & 0 of $10 / 0$ of 10 \\
\hline \multicolumn{6}{|l|}{ Convolvulaceae } \\
\hline Ipomoea violaceae 'Giant White' & Moonflower & $-1-$ & 0 of $10 / 0$ of 10 & nt & nt \\
\hline \multicolumn{6}{|l|}{ Cucurbitaceae } \\
\hline Citrullus lanatus 'Black Diamond' & Watermelon & $-1-$ & 0 of $10 / 0$ of 10 & nt & nt \\
\hline C. lanatus 'Charleston Grey' & Watermelon & $-1-$ & 0 of $10 / 0$ of 10 & nt & nt \\
\hline C. lanatus 'Crimson Sweet' & Watermelon & $-1-$ & 0 of $10 / 0$ of 10 & $\mathrm{nt}$ & nt \\
\hline Cucurbita реро 'Prelude II' & Squash & $-1-$ & 0 of $10 / 0$ of 10 & nt & nt \\
\hline C. pepo 'Zucchini hybrid' & Squash & $-1-$ & 0 of $10 / 0$ of 10 & $\mathrm{nt}$ & nt \\
\hline \multicolumn{6}{|l|}{ Fabaceae } \\
\hline Arachis hypogaea 'Georgia Green' & Peanut & $-1-$ & 0 of $30 / 0$ of 30 & $\mathrm{nt}$ & nt \\
\hline Crotalaria juncea & Sunn hemp & $-1-$ & 0 of $10 / 0$ of 10 & nt & nt \\
\hline Glycine max '93Y92' & Soybean & $-1-$ & 0 of $10 / 0$ of 10 & $-1-$ & 0 of $10 / 0$ of 10 \\
\hline G. $\max$ '95M50' & Soybean & $-1-$ & 0 of $10 / 0$ of 10 & $-1-$ & 0 of $10 / 0$ of 10 \\
\hline G. $\max$ '95Y20' & Soybean & $-1-$ & 0 of $10 / 0$ of 10 & $-1-$ & 0 of $10 / 0$ of 10 \\
\hline \multirow[t]{2}{*}{ G. $\max$ '97M50' } & Soybean & $-1-$ & 0 of $10 / 0$ of 10 & $-1-$ & 0 of $10 / 0$ of 10 \\
\hline & & & & \multicolumn{2}{|c|}{ (Continued on next page) } \\
\hline
\end{tabular}

u Family and species name are according to USDA PLANTS Database (http://plants.usda.gov, accessed October 9, 2012). Cultivar shown where applicable.

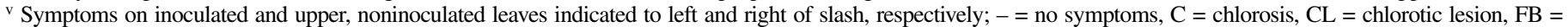
flower break, $\mathrm{M}=$ mottling, $\mathrm{N}=$ necrosis, $\mathrm{NL}=$ necrotic lesion, $\mathrm{NLL}=$ necrotic local lesion, $\mathrm{PD}=$ plant death, $\mathrm{RS}=$ ringspot, $\mathrm{VC}=$ vein clearing, and nt = not tested.

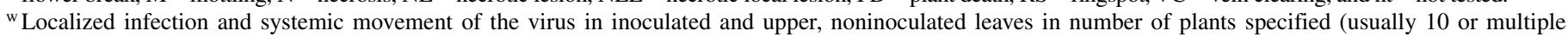
thereof) indicated to left and right of slash, respectively, with infection confirmed by enzyme-linked immunosorbent assay or reverse transcription-polymerase chain reaction.

${ }^{\mathrm{x}}$ Indicates number of plants alive (of original 10) at time of symptom evaluation and virus testing.

y $S$. lycopersicum (tomato) denoted with $S w 5$ has the $S w 5$ gene that confers resistance to Tomato spotted wilt virus.

${ }^{\mathrm{z}}$ Inoculated by mass exposure to viruliferous Frankliniella occidentalis. 
were occasionally seen (data not shown). The relative incidence of the three tospoviruses in infected samples collected in south Florida was interesting. No peanuts with GRSV or TCSV infections were detected. Only TSWV was detected in 57\% of the peanuts collected in south Florida (35 of 61 samples, Table 2) despite the frequent occurrence of GRSV (20\%) and TCSV (16\%) in other hosts in this region during the surveys (Table 2). Only two peppers were found infected with TCSV, whereas 41\% (19 of 46 samples) of peppers from the same region were infected with GRSV and $28 \%$ (13 of 46 samples) were infected with TSWV (Table 2).

Low genetic diversity of GRSV and TCSV isolates. Sequences of portions of the S, M and L genomic RNA segments of GRSV and TCSV isolates from all new hosts and new locations (GenBank accessions KM006992 to KM007037) were compared with previously characterized isolates (GenBank accessions HQ644140, HQ644141, HQ644142, S54325, AF213674, and HQ700667). High levels of nucleotide sequence identity (94 to $100 \%$ ) of all isolates of both viruses to the respective characterized isolates of GRSV or TCSV confirmed initial identifications. The isolates characterized in this study all were highly similar, with fewer than $1 \times 10^{-2}$ substitutions/nucleotide (Table
3). The reassorted nature $\left(\mathrm{L}_{\mathrm{G}} \mathrm{M}_{\mathrm{T}} \mathrm{S}_{\mathrm{G}}\right.$ genotype) of GRSV isolates from all hosts and locations, including South Carolina and New York, was confirmed with greater than $99 \%$ nucleotide identity to previously characterized GRSV isolates from south Florida (data not shown).

Acquisition and transmission of GRSV and TCSV isolates by local thrips populations. Thrips species known to transmit tospoviruses and prevalent in the southeastern United States were tested for their ability to acquire and transmit GRSV (Table 4). F. occidentalis was included due to previous results showing that this species transmitted Florida GRSV isolates (34). There were significant differences in the ability of the four thrips species to acquire GRSV $\left(\chi^{2}=53.65\right.$, df $\left.=3, P<0.0001\right): 30.3 \%$ of $F$. schultzei acquired GRSV, which was a significantly higher rate than for the other three species (Table 4). No F. fusca successfully acquired GRSV. The overall frequency of transmission of GRSV also differed among the species $\left(\chi^{2}=60.79\right.$, df $\left.=3, P<0.0001\right)$. $F$. schultzei transmitted GRSV at a significantly higher rate than the other three species, and F. occidentalis transmitted GRSV at a significantly higher rate than the other two species (Table 4). Although $3.2 \%$ of $F$. bispinosa successfully acquired GRSV, no F. bispinosa transmitted the virus (Table 4). F. fusca was not ob-

TABLE 1. (Continued from previous page)

\begin{tabular}{|c|c|c|c|c|c|}
\hline Family, species, and cultivar ${ }^{\mathrm{u}}$ & Common name & $\begin{array}{c}\text { GRSV } \\
\text { symptoms }^{v}\end{array}$ & $\begin{array}{c}\text { GRSV } \\
\text { presence }^{w}\end{array}$ & $\begin{array}{c}\text { TCSV } \\
\text { symptoms }^{v}\end{array}$ & $\begin{array}{c}\text { TCSV } \\
\text { presence }^{w}\end{array}$ \\
\hline \multicolumn{6}{|l|}{ Fabaceae } \\
\hline Phaseolus vulgaris & Kidney bean & $-1-$ & 0 of $10 / 0$ of 10 & nt & nt \\
\hline P. vulgaris 'Foremost' & Green bean & $-1-$ & 0 of $10 / 0$ of 10 & nt & nt \\
\hline Vigna unguiculata 'California Blackeye \#5' & Cowpea & $-1-$ & 0 of $10 / 0$ of 10 & nt & nt \\
\hline \multicolumn{6}{|l|}{ Malvaceae } \\
\hline Abelmoschus esculentus 'Clemson Spineless' & Okra & $-1-$ & 0 of $10 / 0$ of 10 & nt & nt \\
\hline Gossypium hirsutum 'DES 607' & Cotton & $-1-$ & 0 of $10 / 0$ of 10 & nt & nt \\
\hline \multicolumn{6}{|l|}{ Lamiaceae } \\
\hline Ocimum basilicum & Sweet basil & $-1-$ & 0 of $10 / 0$ of 10 & nt & nt \\
\hline \multicolumn{6}{|l|}{ Rosaceae } \\
\hline $\begin{array}{l}\text { Fragaria } \times \text { ananassa 'Festival' } \\
\text { Rutaceae }\end{array}$ & Strawberry & $-1-$ & 0 of $10 / 0$ of 10 & $-1-$ & 0 of $10 / 0$ of 10 \\
\hline Citrus sinensis 'Ridge Pineapple' & Sweet orange & $-1-$ & 0 of $10 / 0$ of 10 & nt & nt \\
\hline \multicolumn{6}{|l|}{ Solanaceae } \\
\hline Brugmansia $\times$ candida 'Creamsicle' & Angel's trumpet & RS/VC & 7 of $11 / 1$ of 11 & nt & $\mathrm{nt}$ \\
\hline Capsicum annuиm 'Aristotle' & Bell pepper & CL/M,N,RS & 10 of $10 / 9$ of 10 & CL,RS/M,N,RS & 10 of $10 / 10$ of 10 \\
\hline Datura metel & Downy thorn-apple & CL/NL & 6 of $10 / 6$ of 10 & $\mathrm{nt}$ & nt \\
\hline D. stramonium & Jimsonweed & RS/CL,N,RS & 7 of $10 / 7$ of 10 & RS/M,N & 10 of $10 / 10$ of 10 \\
\hline Nicotiana benthamiana & & N,M,RS/N,M,RS & 8 of $10 / 9$ of 10 & CL,RS/C,N & 10 of $10 / 10$ of 10 \\
\hline N. debneyi & & $\mathrm{RS} /-$ & 9 of $10 / 0$ of 10 & nt & nt \\
\hline N. glutinosa & & NLL/- & 8 of $10 / 0$ of 10 & NLL/N & 10 of $10 / 9$ of 10 \\
\hline N. megalosiphon & & RS/RS & 9 of $10 / 10$ of 10 & nt & $\mathrm{nt}$ \\
\hline N. miersii & & $\mathrm{NL}, \mathrm{N} / \mathrm{NL}$ & 10 of $10 / 10$ of 10 & nt & nt \\
\hline N. occidentalis & & RS/RS & 10 of $10 / 6$ of 10 & nt & $\mathrm{nt}$ \\
\hline N. rustica & & $\mathrm{NL} / \mathrm{N}, \mathrm{M}$ & 7 of $10 / 7$ of 10 & N,RS/-,PD & 9 of $9 / 3$ of $9^{x}$ \\
\hline N. sylvestris & & $\mathrm{NL} / \mathrm{N}, \mathrm{M}$ & 5 of $10 / 1$ of 10 & NL,RS/- & 10 of $10 / 1$ of 10 \\
\hline N. tabacuum 'Xanthi' & Tobacco & NL/M & 8 of $10 / 6$ of 10 & $\mathrm{RS} /-, \mathrm{PD}$ & 7 of $8 / 4$ of $8^{x}$ \\
\hline N. tabacuum 'Xanthi nc' & Tobacco & NL/- & 8 of $10 / 3$ of 10 & RS/- & 9 of $10 / 2$ of 10 \\
\hline Petunia $\times$ hybrida 'Blue Supercascade' & Petunia & -/NL,RS,FB & 0 of $10 / 1$ of 10 & $\mathrm{~N}, \mathrm{RS} / \mathrm{N}, \mathrm{RS}, \mathrm{VC}$ & 10 of $10 / 8$ of 10 \\
\hline P. $\times$ hybrida 'Red Supercascade' & Petunia & NL/N,RS,FB,PD & 1 of $4 / 2$ of $4^{x}$ & N,RS/N,RS,PD & 9 of $9 / 8$ of $9^{x}$ \\
\hline P. $\times$ hybrida 'Rose Wave Hybrid' & Petunia & NL/N,RS,FB,PD & 0 of $9 / 4$ of $9^{x}$ & $\mathrm{nt}$ & $\mathrm{nt}$ \\
\hline Physalis philadelphica 'Burpee Green' & Tomatillo & $\mathrm{RS}, \mathrm{N}, \mathrm{M} / \mathrm{RS}, \mathrm{N}, \mathrm{M}$ & 11 of $28 / 12$ of 28 & $\mathrm{C}, \mathrm{N} / \mathrm{C}, \mathrm{N}, \mathrm{PD}$ & 4 of $4 / 4$ of $4^{x}$ \\
\hline P. pruinosa 'Goldie' & Husk Cherry & $\mathrm{RS}, \mathrm{N}, \mathrm{M} / \mathrm{RS}, \mathrm{N}, \mathrm{M}$ & 3 of $9 / 7$ of 9 & $\mathrm{nt}$ & nt \\
\hline Solanum americanum & American black nightshade & $\mathrm{RS} / \mathrm{RS}$ & 8 of $10 / 7$ of 10 & $-/ \mathrm{M}, \mathrm{N}$ & 8 of $10 / 8$ of 10 \\
\hline S. bahamense & Key West nightshade & $-/ \mathrm{N}, \mathrm{C}$ & 2 of $9 / 8$ of 9 & $\mathrm{nt}$ & nt \\
\hline S. lycopersicum 'Black Cherry' & Tomato & $-1-$ & 1 of $10 / 0$ of 10 & nt & $\mathrm{nt}$ \\
\hline S. lycopersicum 'Black Prince' & Tomato & $-1-$ & 1 of $10 / 6$ of 10 & $-/ \mathrm{N}, \mathrm{NL}$ & 8 of $10 / 9$ of 10 \\
\hline S. lycopersicum 'Florida 47' & Tomato & $-/ \mathrm{M}, \mathrm{N}, \mathrm{RS}$ & 14 of $20 / 18$ of 20 & CL/M,N,RS & 11 of $20 / 16$ of 20 \\
\hline S. lycopersicum 'Matt's Wild Cherry' & Tomato & $-1-$ & 7 of $10 / 5$ of 10 & $-/ \mathrm{N}, \mathrm{NL}$ & 6 of $10 / 9$ of 10 \\
\hline S. lycopersicum 'Moskvich' & Tomato & $-1-$ & 5 of $10 / 4$ of 10 & $-/ \mathrm{N}, \mathrm{NL}$ & 7 of $10 / 8$ of 10 \\
\hline S. lycopersicum 'Purple Calabash' & Tomato & $-1-$ & 0 of $10 / 5$ of 10 & $-/ \mathrm{M}, \mathrm{N}, \mathrm{RS}$ & 7 of $10 / 9$ of 10 \\
\hline S. lycopersicum 'Quincy' $(S w 5)^{\mathrm{y}}$ & Tomato & $-1-$ & 0 of $10 / 0$ of 10 & nt & nt \\
\hline S. lycopersicum 'Tygress' & Tomato & $-/ \mathrm{M}, \mathrm{N}$ & 2 of $20 / 8$ of 20 & $-/ \mathrm{M}, \mathrm{N}, \mathrm{RS}$ & 5 of $10 / 8$ of 10 \\
\hline S. melongena 'Nightshadow' & Eggplant & $\mathrm{RS} / \mathrm{RS}, \mathrm{M}$ & 5 of $10 / 1$ of 10 & N,RS/- & 5 of $10 / 0$ of 10 \\
\hline S. melongena 'Nightshadow'z & Eggplant & nt & nt & N,RS/- & 11 of $12 / 0$ of 12 \\
\hline \multicolumn{6}{|l|}{ Tropaeolaceae } \\
\hline Tropaeolum majus 'Double Gleam Mix' & Nasturtium & $-1-$ & 0 of $10 / 0$ of 10 & $\mathrm{nt}$ & $\mathrm{nt}$ \\
\hline
\end{tabular}


served to transmit GRSV. When considering only the rate of transmission by thrips that tested positive for the virus (adjusted transmission rate for viruliferous thrips), the rate of viruliferous F. schultzei transmitting GRSV was $64.7 \%$, but this was only significantly higher than the rate for $F$. bispinosa $(0.0 \%)$.

Both acquisition and transmission frequency were significantly higher for TCSV than GRSV by $F$. occidentalis $\left(\chi^{2}=98.58, \mathrm{df}=1\right.$, $P<0.0001$ acquisition; $\chi^{2}=6.09, \mathrm{df}=1, P=0.014$ transmission). Acquisition by $F$. occidentalis of TCSV was $36.8 \%$ compared with $5.9 \%$ acquisition for GRSV (Table 4). Likewise, the overall transmission rate was $11.8 \%$ for TCSV versus $6.4 \%$ for GRSV. However, the adjusted rates of transmission for viruliferous thrips were not significantly different between the virus species $(21.5 \%$ for TCSV versus $28.6 \%$ for GRSV; $\chi^{2}=0.38, \mathrm{df}=1, P=0.54$ ), suggesting that, once acquired, both viruses were transmitted with equal efficiency by $F$. occidentalis.

\section{DISCUSSION}

The ability of an insect-transmitted pathogen to become established and impact crops when introduced to a new geographic area depends on several factors. In annual crop production, these would include the presence of suitable reservoir hosts to enable survival when the crop is not in production, and an insect vector that reproduces and feeds on both the crop and reservoir hosts to enable movement. Although TSWV has severely impacted agriculture across the southeastern United States over many years (28), much less information is available regarding potential impacts of GRSV and TCSV. Our geographic distribution survey and host range studies show the widespread presence of both GRSV and TCSV in vegetable production regions of south Florida and that numerous suitable reservoirs are present to facilitate the persistence of these invasive viruses. Our virus acquisition and transmission tests indicate that thrips species common in Florida and elsewhere in the southeastern United States are competent vectors of these viruses. Together this information documents the establishment of both virus species in south Florida vegetable and vegetable transplant production areas, and the potential threat to other geographic areas.

All three viruses occurred in sympatry in the majority of the ten counties sampled in south Florida. It was common to find two of the three viruses in the same field but much less common to find them infecting a single plant (7 of 431 tospovirus-infected samples; Table 2) similar to previous observations $(33,34)$. However, the percentage of samples infected with GRSV or TCSV fluctuated over the course of the study, such that only TCSV (but no GRSV) was detected in south Florida in the last half of 2013. The initial sympatry of the three species in tomato and pepper in south Florida may be due to a common route and near concurrent introduction of GRSV and TCSV to the state. Results from south Florida parallel results from Argentina where GRSV, TCSV, and TSWV are also known to exist. Gracia et al. (14) found all three viruses present in the tomato production areas of Mendoza and Buenos Aires Provinces in Argentina. However, in a similar study conducted in the same region 1 to 2 years later, a distinct geographic segregation of the viruses was found although the reasons for these changes were not fully explored (39).

Across south Florida, multiple solanaceous vegetables and weeds were found to be hosts, in some cases new hosts, of GRSV and/or TCSV in field surveys (Table 2). These findings corresponded with those from experimental host range inoculations (Table 1). Neither GRSV nor TCSV was found in other reported hosts (e.g., peanut and soybean) in field surveys, which also corresponded with our inability to infect a variety of leguminous and other plants by mechanical inoculation in our experimental host range studies (Table 1). For the one plant species (eggplant) in which we compared thrips-mediated with mechanical inoculation, no differences in symptoms (necrosis and ringspots) or distribution of TCSV (local but no systemic infections) were observed, although the number of locally infected plants essen-
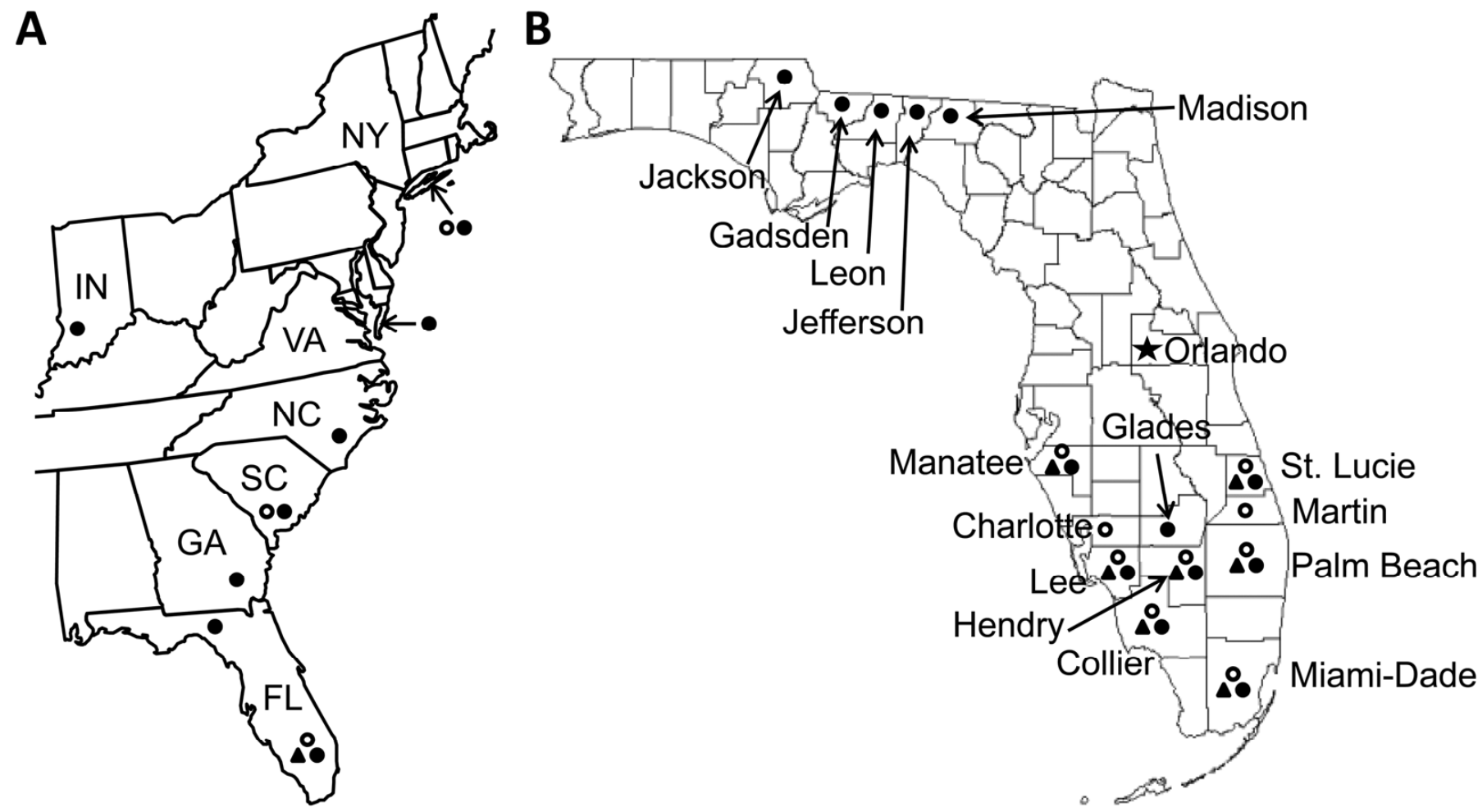

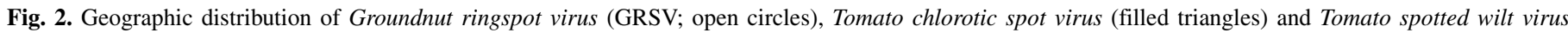

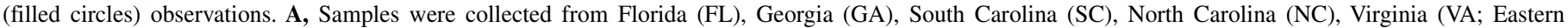

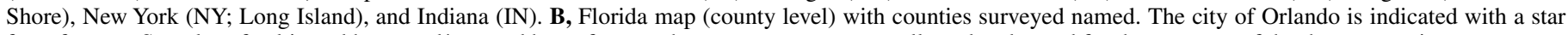
for reference. Samples of cultivated hosts and/or weed hosts from each state or county were collected and tested for the presence of the three tospoviruses. 
tially doubled with thrips-mediated inoculation (Table 1). This suggests that thrips-mediated inoculation was more efficient than mechanical inoculation and raises the possibility that results of our experimental host range studies may have been influenced by the inoculation method. However, correspondence between TCSV symptoms and distribution in lettuce during a recent epidemic in Puerto Rico (13) with results of our experimental host range studies (Table 1) demonstrates the continued usefulness of such studies. All GRSV and TCSV isolates selected for additional sequence characterization from new hosts and new locations displayed low genetic diversity (Table 3). All GRSV isolates characterized in this study, including those from South Carolina and New York, had the same reassorted $\left(\mathrm{L}_{\mathrm{G}} \mathrm{M}_{\mathrm{T}} \mathrm{S}_{\mathrm{G}}\right)$ genotype that was originally reported for Florida isolates (34). This low genetic diversity for both GRSV and TCSV isolates analyzed in this study is likely due to the recent introductions of both viruses to the United States.
Experimental transmission assays demonstrated that thrips vectors of Florida GRSV isolates include $F$. schultzei, in addition to the previously reported $F$. occidentalis (34). Significantly higher acquisition and transmission rates of GRSV were observed for $F$. schultzei (30.3 and 24.1\%, respectively; Table 4) than for $F$. occidentalis (5.9 and 6.4\%, respectively; Table 4). This suggests that $F$. schultzei is a contributor to outbreaks of GRSV in Florida even though this species was present in relatively low numbers in tomato and pepper blooms analyzed in this study (data not shown). However, F. schultzei has recently been observed breeding on cucurbitaceous and solanaceous crops in Miami-Dade County $(17,18)$. At present it does not seem likely that cucurbit crops are a significant host of GRSV in Florida because impatiens was the only non-solanaceous host that became infected when mechanically inoculated with GRSV. We specifically tested watermelon and other cucurbit species in the GRSV experimental host range because cucurbit flowers were the major source of $F$.

TABLE 2. Geographic and temporal distribution of tospoviruses in crop and weed species in surveyed areas

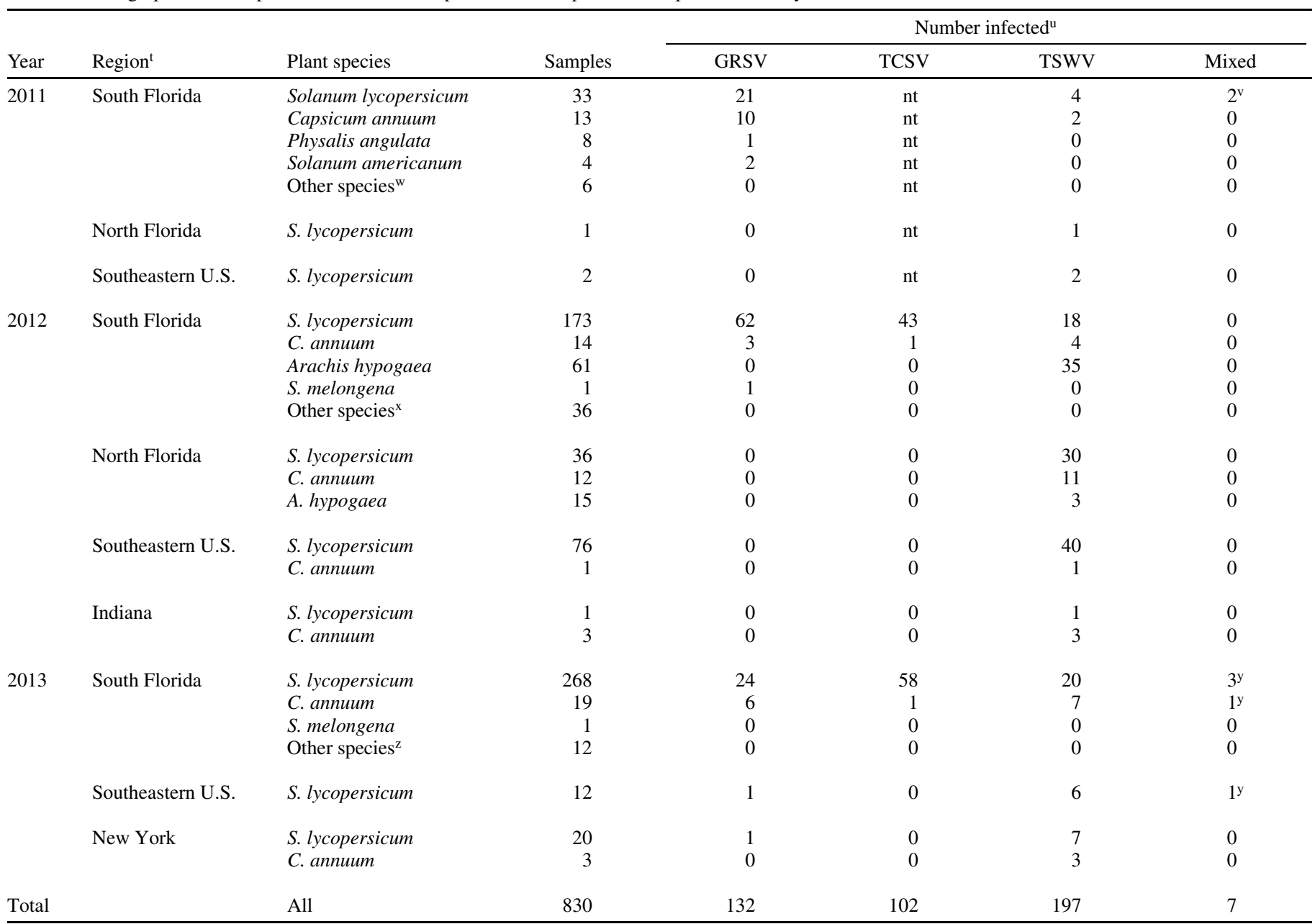

${ }^{\mathrm{t}}$ Geographic regions from which samples were collected: south Florida (Charlotte, Collier, Glades, Hendry, Lee, Manatee, Martin, Miami-Dade, Palm Beach, and St. Lucie Counties), north Florida (Gadsden, Jackson, Jefferson, Leon, and Madison Counties), southeastern United States (Georgia, South Carolina, North Carolina and Virginia), Indiana (Knox County), and New York (Suffolk County).

" Number of samples infected with Groundnut ringspot virus (GRSV), Tomato chlorotic spot virus (TCSV), Tomato spotted wilt virus (TSWV), or combinations thereof (Mixed). All samples tested by enzyme-linked immunosorbent assay with selected samples confirmed by reverse transcription-polymerase chain reaction (RT-PCR) prior to detection of TCSV in Florida in 2012 ( $\mathrm{nt}$ = not tested for TCSV), after which all samples were tested by RT-PCR.

$\checkmark$ Two S. lycopersicum samples with mixed GRSV and TSWV infections were found in south Florida in 2011.

${ }^{w}$ Other species tested in 2011: Glycine max, Macroptilium lathyroides, and unknown legume.

${ }^{x}$ Other species tested in 2012: Ambrosia artemisiifolia, Bidens pilosa, Citrullus lanatus, Eclipta prostrata, Gamochaeta pensylvatica, Ipomoea batatas, Lactuca canadensis, Melothria pendula, Origanum vulgare, Parthenium hysterophorus, Phaseolus vulgaris, Physalis angulata, S. americanum, S. tuberosum, unknown legume, and Wedelia trilobata.

${ }^{y}$ Two $S$. lycopersicum samples with mixed GRSV and TCSV infections, one $S$. lycopersicum sample with a mixed TCSV and TSWV infection, and one $C$. апnиum sample with a mixed TCSV and TSWV infection were found in south Florida in 2013. One S. lycopersicum sample with a mixed GRSV and TSWV infection was found in South Carolina in 2013.

${ }^{\text {z }}$ Other species tested in 2013: Bidens pilosa, Lactuca sativa, Physalis philadelphica, S. americanum, and S. tuberosum. 
schultzei for our transmission experiments. Larvae of F. schultzei and other thrips species must acquire tospoviruses by feeding on infected plants to subsequently transmit as adults. Thus, F. schultzei or any other thrips species developing on noninfected cucurbits would likely not contribute to the primary spread of GRSV or TCSV.

A common thrips species present in south Florida flowers is $F$. bispinosa, which is known to be a TSWV vector (2). In our transmission studies, a small percentage of $F$. bispinosa acquired GRSV (3.2\%, Table 4). However, no transmission by F. bispinosa was observed, suggesting that this species is not readily able to transmit Florida GRSV isolates. Similar acquisition of tospovirus but vector incompetence is known to occur in other thrips species, and is presumably due to a lack of movement of the virus to the salivary glands, as reported previously (8), although further investigation is required. Our characterization of the ability of common thrips species in the southeastern United States to acquire and transmit GRSV provides a sound basis for future research to determine the role each vector and plant species plays in the epidemiology of GRSV in southeastern tomato and pepper production. Because known vector determinants are present on tospovirus M RNA genome segments, and because GRSV isolates analyzed from Florida, South Carolina, and New York are all reassortants containing the TCSV M RNA, it is likely that our acquisition and transmission results will be broadly applicable to TCSV.

We specifically compared the ability of $F$. occidentalis to acquire and transmit TCSV and GRSV. TCSV was both acquired and transmitted by $F$. occidentalis at a significantly higher rate than GRSV (Table 4). However, once thrips acquired the virus, similar transmission rates by viruliferous $F$. occidentalis were observed for TCSV (21.5\%) and GRSV (28.6\%), which parallels previous results comparing GRSV and TSWV transmission (34). This suggests that acquisition efficiency is important in determining population level tospovirus transmission rates, with GRSV, TCSV, and TSWV having quite similar rates of transmission by $F$. occidentalis once thrips acquired the virus. Given the nonreassorted genotype of Florida TCSV isolates, it is also expected that $F$. schultzei and other known TCSV vectors $(23,37)$ will play a role in Florida, although plant host, virus isolate and thrips biotype may affect the transmission rates $(10,37)$. While there are relatively low populations of $F$. schultzei in Florida, higher populations are found in Puerto Rico where TCSV has recently become a significant limitation to vegetable production $(13,32)$. Thus, management of $F$. schultze $i$ should be included in integrated pest management strategies for these viruses.

Our inability to infect peanut plants with GRSV and the absence of GRSV in peanut plants with tospovirus symptoms in this study is of interest because peanut is the originally reported host of GRSV (9). No symptoms were observed and no virus was detected in peanut despite repeated mechanical inoculation of peanut plants with GRSV, even using methods shown to be effective for mechanical inoculation of peanut with TSWV (21). It is likely that previous reports of peanut inoculations with GRSV $(9,11)$ made use of non-reassorted isolates. Perhaps the reassorted nature of GRSV isolates present in Florida, South Carolina, and New York renders these isolates incapable of infecting peanut. The presence of the TCSV M RNA, which encodes the NSm movement protein and the $\mathrm{G}_{\mathrm{N}}$ and $\mathrm{G}_{\mathrm{C}}$ glycoproteins, may be sufficient to alter the host range and/or the vector range of the reassorted GRSV isolates. Such alterations may also explain our observations of no GRSV infection in peanuts with tospovirus

TABLE 3. Genetic diversity of Groundnut ringspot virus (GRSV) and Tomato chlorotic spot virus (TCSV) from the United States

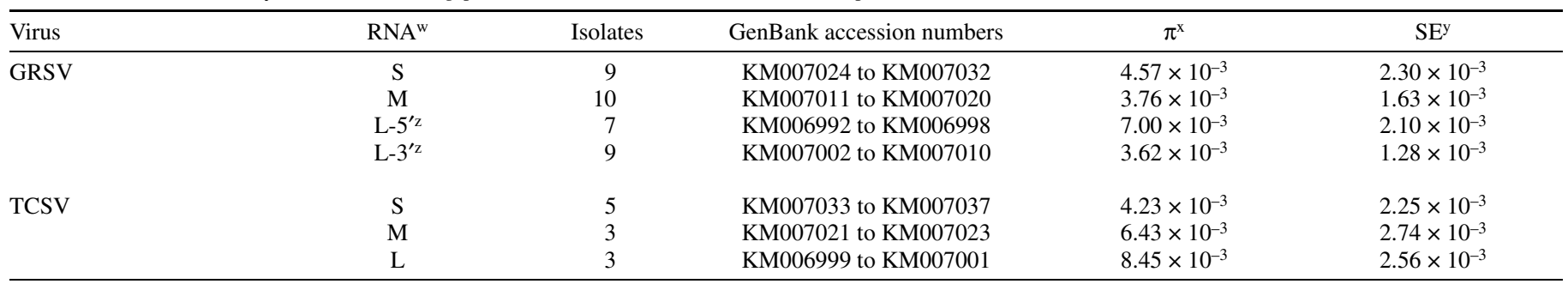

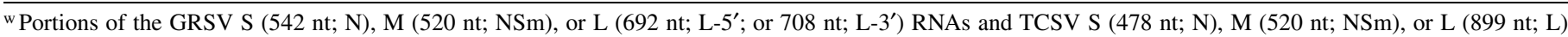
RNAs from virus isolates collected from all new hosts and new locations reported.

${ }^{\mathrm{x}}$ Mean nucleotide diversity $(\pi)$ of the pairwise comparisons of each sequence was calculated within MEGA 4.1 using pairwise deletion and a maximum composite likelihood substitution model.

${ }^{y}$ Standard error (SE) of the mean computed using bootstrapping with 1,000 replications.

${ }^{z} 5^{\prime}$ and $3^{\prime}$ portions of the L gene on the L RNA were sequenced for different isolates of GRSV.

TABLE 4. Acquisition and transmission of Groundnut ringspot virus (GRSV) by locally important thrips species (top portion of the table) and acquisition and transmission of Tomato chlorotic spot virus (TCSV) and GRSV by Franklinella occidentalis (lower portion of the table)

\begin{tabular}{llccc}
\hline & \multicolumn{1}{c}{ Species } & Virus acquisition $^{\mathrm{x}}$ & Virus transmission $^{\mathrm{y}}$ & Adjusted transmission $^{\mathrm{z}}$ \\
\hline Thrips & F. schultzei & $30.3 \%(17 / 56) \mathrm{a}$ & $24.1 \%(14 / 58) \mathrm{a}$ & $64.7 \%(11 / 17) \mathrm{a}$ \\
& F. occidentalis & $5.9 \%(22 / 373) \mathrm{b}$ & $6.4 \%(25 / 389) \mathrm{b}$ & $28.6 \%(6 / 21) \mathrm{ab}$ \\
F. bispinosa & $3.2 \%(5 / 156) \mathrm{b}$ & $0.0 \%(0 / 228) \mathrm{c}$ & $0.0 \%(0 / 5) \mathrm{b}$ \\
V. $\mathrm{b}$ (usca & $0.0 \%(0 / 39) \mathrm{b}$ & $0.0 \%(0 / 81) \mathrm{c}$ & - \\
& TCSV & $36.8 \%(103 / 280) a$ & $11.8 \%(34 / 287) a$ & $21.5 \%(23 / 103) a$ \\
& GRSV & $5.9 \%(22 / 373) b$ & $6.4 \%(25 / 389) b$ & $28.6 \%(6 / 21) a$ \\
\hline
\end{tabular}

${ }^{\mathrm{x}}$ Virus acquisition determined by enzyme-linked immunosorbent assay (ELISA) or reverse transcription-polymerase chain reaction (RT-PCR) and presented as the number of positive thrips/total number tested. Thrips or virus species sharing the same letter (regular type for thrips and italicized for viruses) are not significantly different according to Tukey-style multiple comparisons of proportions $(\alpha=0.05)$.

${ }^{y}$ Virus transmission to noninfected leaf discs determined by ELISA or RT-PCR and presented as the number of positive discs/total number tested. Thrips or virus species sharing the same letter (regular type for thrips and italicized for viruses) are not significantly different according to Tukey-style multiple comparisons of proportions $(\alpha=0.05)$.

${ }^{\mathrm{z}}$ Transmission efficiency using results from viruliferous thrips only presented as the percentage of virus-positive leaf discs from the number of leaf discs fed upon by viruliferous thrips. Numbers in parentheses indicate the total number of virus-positive leaf discs/number of viruliferous thrips. Thrips or virus species sharing the same letter (regular type for thrips and italicized for viruses) are not significantly different according to Tukey-style multiple comparisons of proportions ( $\alpha=$ $0.05)$. 
symptoms sampled from areas containing GRSV in south Florida (Table 2) and the lack of acquisition or transmission of GRSV by F. fusca (Table 4).

GRSV was found in single tomato samples from South Carolina and from New York, but it is not yet clear if these findings reflect establishment of GRSV in these locations or detections of chance infections that may or may not be maintained in the ecosystem. Suitable plant hosts (including weed species) and vectors (F. occidentalis) are present in both South Carolina and New York, and across the wider United States. Both states lack significant populations of $F$. schultzei, the most efficient vector yet determined, and have considerably colder winters than Florida. Such factors are likely important for establishment of GRSV and TCSV in new geographic areas.

GRSV and TCSV were identified primarily in south Florida and only GRSV was found outside of Florida in the areas we surveyed. Both viruses appear mostly limited to infections of tomato and other solanaceous vegetables, ornamentals, and weeds, although two non-solanaceous hosts were infected by mechanical inoculation. This suggests that these GRSV and TCSV isolates will remain primarily of concern to tomato, pepper, and other solanaceous crop producers. However, TCSV may become an issue for lettuce producers as recently observed in Puerto Rico (13). Both viruses infected impatiens in our study, and likely infect a wider range of ornamentals than we have tested. The $S w 5$ gene for TSWV resistance in tomato also conferred resistance to GRSV ('Quincy' in Table 1) as observed previously (34). However, the between cultivar variability in symptoms and susceptibility to GRSV and/or TCSV observed within species including lettuce, tomato, and petunia makes generalizations across these species difficult.

While F. schultzei is an efficient vector of GRSV, TCSV, and TSWV, it currently has a relatively limited distribution within the continental United States and thus is not likely to become a widely important tospovirus vector outside of Florida in the near future. Additionally, the preference of $F$. schultzei for cucurbit flowers coupled with the inability of GRSV to infect cucurbits, suggests a minor role for $F$. schultzei in field transmission of GRSV and TCSV even in Florida. However, F. occidentalis is widespread within the continental United States and able to transmit GRSV and TCSV, and likely plays a major role in field spread of GRSV and TCSV in Florida. The presence of $F$. occidentalis in South Carolina and New York, states from which detection of GRSV is first reported in this work, gives the potential for GRSV transmission in these states.

The potential for further spread of these emerging tospovirus species exists, especially given detection of GRSV and TCSV in tomato transplants, and ongoing vigilance is needed to observe and test suspect samples. The rapid change in tospovirus species in Florida with the initial appearance of GRSV and the subsequent appearance of TCSV serves as a warning. Nucleic acidbased tests are required for accurate identification because of the highly similar symptoms induced by GRSV, TCSV, and TSWV in tomato and pepper, and inability of currently used serological tests to unequivocally distinguish these species. It is possible that GRSV and/or TCSV are already present elsewhere in the United States but have been misdiagnosed as TSWV. Although not common, infections of a single plant with GRSV and TSWV, GRSV and TCSV, or TCSV and TSWV reported here and previously $(33,34)$ suggest that tospovirus diagnostics are likely to become more complex through additional reassortment of tospovirus genomic RNAs. Clearly, GRSV and TCSV were both present in a single plant or thrips and able to exchange M RNA segments to create the GRSV reassortant first found in Florida. Our detection of this same GRSV reassortant in South Carolina and New York, where TSWV is already established, provides early warning of new locations where further reassortment may occur.

\section{ACKNOWLEDGMENTS}

We thank C. Vanderspool, K. Bowers, A. Moreno, and B. Burns for their excellent technical assistance, numerous scouts and growers for help with sample collection, J. Marois for soybean seeds, and E. Rosskopf and $\mathrm{N}$. Burelle for tomato seeds. Financial support was provided in part by grants from the USDA-NIFA Critical Issues (2011-37610-31178), Florida Specialty Crop Block Grant (018014) and USDA-AFRI (2012-6800420166) programs, and the Florida Tomato Committee, the Florida Specialty Crop Foundation, and the Florida Fruit and Vegetable Association. Mention of a trademark, warranty, proprietary product, or vendor does not constitute a guarantee by the U.S. Department of Agriculture and does not imply its approval to the exclusion of other products or vendors that also may be suitable.

\section{LITERATURE CITED}

1. Adkins, S., and Rosskopf, E. N. 2002. Key West nightshade, a new experimental host for plant viruses. Plant Dis. 86:1310-1314.

2. Avila, Y., Stavisky, J., Hague, S., Funderburk, J., Reitz, S., and Momol, T. 2006. Evaluation of Frankliniella bispinosa (Thysanoptera: Thripidae) as a vector of the Tomato spotted wilt virus in pepper. Florida Entomol. 89:204-207.

3. Batuman, O., Rojas, M. R., Almanzar, A., and Gilbertson, R. L. 2014. First report of Tomato chlorotic spot virus in processing tomatoes in the Dominican Republic. Plant Dis. 98:286.

4. Boari, A. J., Maciel-Zambolim, E., Lau, D. D., Lima, G. A., Kitajima, E. W., Brommonschenkel, S. S. H., and Zerbini, F. M. 2002. Detection and partial characterization of an isolate of Groundnut ringspot virus in Solanum sessiliflorum. Fitopatol. Bras. 27:249-253.

5. Briese, T., Calisher, C. H., and Higgs, S. 2013. Viruses of the family Bunyaviridae: Are all available isolates reassortants? Virology 446:207216.

6. Culbreath, A. K., Csinos, A. S., Bertrand, P. F., and Demski, J. W. 1991. Tomato spotted wilt virus epidemic in flue-cured tobacco in Georgia USA. Plant Dis. 75: 483-485.

7. Culbreath, A. K., and Srinivasan, R. 2011. Epidemiology of spotted wilt disease of peanut caused by Tomato spotted wilt virus in the southeastern U.S. Virus Res. 159:101-109.

8. de Assis Filho, F. M., Stavisky, J., Reitz, S. R., Deom, C. M., and Sherwood, J. L. 2005. Midgut infection by Tomato spotted wilt virus and vector incompetence of Frankliniella tritici. J. Appl. Entomol. 129:548550.

9. de Ávila, A. C., Huguenot, C., Resende, R. O., Kitajima, E. W., Goldbach, R. W., and Peters, D. 1990. Serological differentiation of 20 isolates of Tomato spotted wilt virus. J. Gen. Virol. 71:2801-2807.

10. de Borbón, C. M., Gracia, O., and Piccolo, R. 2006. Relationship between tospovirus incidence and thrips populations on tomato in Mendoza, Argentina. J. Phytopathol. 154:93-99.

11. de Breuil, S., Abad, J. A., Nome, C. F., Giolitti, F. J., Lambertini, P. L., and Lenardon, S. 2007. Groundnut ringspot virus: An emerging Tospovirus inducing disease in peanut crops. J. Phytopathol. 155:251-254.

12. Demirozer, O., Tyler-Julian, K., Funderburk, J., Leppla, N., and Reitz, S. 2012. Frankliniella occidentalis (Pergande) integrated pest management programs for fruiting vegetables in Florida. Pest Manag. Sci. 68:15371545.

13. Estévez de Jensen, C., and Adkins, S. 2014. First report of Tomato chlorotic spot virus in lettuce in Puerto Rico. Plant Dis. 98:1015.

14. Gracia, O., de Borbón, C. M., Granval de Millan, N., and Cuesta, G. V. 1999. Occurrence of different tospoviruses in vegetable crops in Argentina. J. Phytopathol. 147:223-227.

15. Jacobson, A. L., Booth, W., Vargo, E. L., and Kennedy, G. G. 2013. Thrips tabaci population genetic structure and ploidy in relation to competency as a vector of Tomato spotted wilt virus. PLoS ONE 8:e54484.

16. Jacobson, A. L., and Kennedy, G. G. 2013. Specific insect-virus interactions are responsible for variation in competency of different Thrips tabaci isolines to transmit different Tomato spotted wilt virus isolates. PLOS ONE 8:e54567.

17. Kakkar, G., Seal, D. R., and Kumar, V. 2012. Assessing abundance and distribution of an invasive thrips Frankliniella schultzei (Thysanoptera: Thripdae) in south Florida. Bull. Entomol. Res. 102:249-259.

18. Kakkar, G., Seal, D. R., Stansly, P. A., Liburd, O. E., and Kumar, V. 2012. Abundance of Frankliniella schultzei (Thysanoptera: Thripdae) in flowers on major vegetable crops of south Florida. Florida Entomol. 95:468-457.

19. Lima, M. F., de Ávila, A. C., da G. Wanderly, L. J., Jr., Nagata, T., and de Gama, L. J. W. 1999. Coriander: A new natural host of Groundnut ringspot virus in Brazil. Plant Dis. 83:878. 
20. Londoño, A., Capobianco, H., Zhang, S., and Polston, J. E. 2012. First record of Tomato chlorotic spot virus in the USA. Tropical Plant Pathol. 37:333-338.

21. Mandal, B., Pappu, H. R., and Culbreath, A. K. 2001. Factors effecting mechanical transmission of Tomato spotted wilt virus to peanut (Arachis hypogaea). Plant Dis. 85:1259-1263.

22. Martínez, R. T., Poojari, S., Tolin, S. A., Cayetano, X., and Naidu, R. A. 2014. First report of Tomato spotted wilt virus in peppers and tomato in the Dominican Republic. Plant Dis. 98:163.

23. Nagata, T., Almeida, A. C. L., Resende, R. O., and de Ávila, A. C. 2004. The competence of four thrips species to transmit and replicate four tospoviruses. Plant Pathol. 53:136-140.

24. Parrella, G., Gognalons, P., Gebre-Selassie, K., Vovlas, C., and Marchoux, G. 2003. An update of the host range of Tomato spotted wilt virus. J. Plant Pathol. 85:227-264.

25. Qiu, W. P., Geske, S. M., Hickey, C. M., and Moyer, J. W. 1998. Tomato spotted wilt virus Tospovirus genome reassortment and genome segmentspecific adaption. Virology 244:186-194.

26. Qiu, W. P., and Moyer, J. W. 1999. Tomato spotted wilt tospovirus adapts to the TSWV N gene-derived resistance by genome reassortment. Phytopathology 89:186-194.

27. Riley, D. G., Joseph, S. V., Srinivasan, R., and Diffie, S. 2011. Thrips vectors of tospoviruses. J. Integ. Pest Mngmt. 1:1-10.

28. Scholthof, K.-B. G., Adkins, S., Czosnek, H., Palukaitis, P., Jacquot, E., Hohn, T., Hohn, B., Saunders, K., Candresse, T., Ahlquist, P., Hemenway, C., and Foster, G. D. 2011. Top 10 plant viruses in molecular plant pathology. Mol. Plant Pathol. 12:938-954.

29. Silva, M. S., Martins, C. R. F., Bezerra, I. C., Nagata, T., de Ávila, A. C., and Resende, R. O. 2001. Sequence diversity of $\mathrm{NS}_{\mathrm{M}}$ movement proteins of tospoviruses. Arch. Virol. 146:1267-1281.

30. Tamura, K., Dudley, J., Nei, M., and Kumar, S. 2007. MEGA4: Molecular evolutionary genetics analysis (MEGA) software version 4.0. Mol. Biol. Evol. 24:1596-1599.

31. Tentchev, D., Verdin, E., Marchal, C., Jacquet, M., Aguilar, J. M., and
Moury, B. 2010. Evolution and structure of Tomato spotted wilt virus populations: Evidence of extensive genome reassortment and insights into emergence process. J. Gen. Virol. 92:961-973.

32. Webster, C. G., Estévez de Jensen, C., Rivera-Vargas, L. I., Rodrigues, J.-C. V., Mercado, W., Frantz, G., Mellinger, H. C., and Adkins, S. 2013. First report of Tomato chlorotic spot virus (TCSV) in tomato, pepper and Jimsonweed in Puerto Rico. Plant Health Progress doi:10.1094/PHP2013-0812-01-BR

33. Webster, C. G., Perry, K. L., Lu, X., Horsman, L., Frantz, G., Mellinger, C., and Adkins, S. 2010. First report of Groundnut ringspot virus infecting tomato in south Florida. Plant Health Progress doi:10.1094/ PHP-2010-0707-01-BR

34. Webster, C. G., Reitz, S. R., Perry, K. L., and Adkins, S. 2011. A natural M RNA reassortment arising from two species of plant- and insectinfecting bunyaviruses and comparison of its sequence and biological properties to parental species. Virology 413:216-225.

35. Webster, C. G., Turechek, W. W., Mellinger, H. C., Frantz, G., Roe, N., Yonce, H., Vallad, G., and Adkins, S. 2011. Expansion of Groundnut ringspot virus host and geographic ranges in solanaceous vegetables in peninsular Florida. Plant Health Progress doi:10.1094/PHP-2011-0725-01-BR

36. Whitfield, A. E., Ullman, D. E., and German, T. L. 2005. Tospovirusthrips interactions. Annu. Rev. Phytopathol. 43:459-489.

37. Wijkamp, I., Almarza, N., Goldbach, R., and Peters, D. 1995. Distinct levels of specificity in thrips transmission of tospoviruses. Phytopathology 85:1069-1074.

38. Wijkamp, I., Goldbach, R., and Peters, D. 1996. Differential susceptibilities between leaf disks and plants in the transmission of tomato spotted wilt virus by Frankliniella occidentalis to TSWV hosts and transgenic plants. J. Phytopathol. 144:355-362.

39. Williams, L. V., Lambertini, P. L., Shohara, K., and Biderbost, E. B. 2001. Occurrence and geographical distribution of tospovirus species infecting tomato crops in Argentina. Plant Dis. 85:1227-1229.

40. Zar, J. H. 1999. Biostatistical Analysis, 4th ed. Prentice Hall, Upper Saddle River, NJ. 